\title{
8. Impressions, observations and lessons from a Canberra outsider ${ }^{1}$
}

\author{
Robert Cornall
}

Robert Cornall was born in Melbourne, went to school at Wesley College, and graduated in law from Melbourne University. He began his career in 1969 as a solicitor at Middletons Oswald Burt, becoming a partner there in 1972. From 1987 to 1995 he was Executive Director and Secretary of the Law Institute of Victoria. Then from 1995 to 2000 he was Managing Director of Victorian Legal Aid. This 19-year stint as a solicitor instilled in him a private sector mindset and has guided his approach to client service ever since. So when Robert Cornall began as Secretary of the Attorney-General's Department in 2000, he transformed the department and improved its performance by emphasising its outward or client focus - an approach he remained committed to until his retirement from the post eight years later.

My appointment as a secretary in the Australian Public Service was as much a surprise to me as it was to officers of the Attorney-General's Department. It came about in this way. The outgoing Secretary, Tony Blunn, rang me one day in November 1999 in my office at Victoria Legal Aid in Melbourne. He told me he was going to retire and he wondered if I was interested in being considered for his position. At that time, I had been the first managing director of VLA for four hectic years. It had been a hard and controversial task establishing that new organisation to overcome what both the Victorian and Australian governments assessed were the deficiencies of the former Legal Aid Commission. I had reached the stage where I felt I had completed that assignment but I hadn't started to think about looking for another job.

So I said, in a rather offhand fashion, that I might be. This was, I should say, a nonchalance brought on by the unexpectedness of the enquiry and a lack of any detailed understanding of the position's interest, importance and challenge.

Tony replied, in that case, it would be a good idea if we could meet as soon as possible to discuss the matter in more detail. He asked: 'How are you placed tomorrow?' I said I had some commitments in the afternoon so I couldn't go to Canberra but I would be available in the morning in Melbourne. Tony said he would be at my office at 11 o'clock. When I put down the phone, I thought: 'Bloody hell! He's serious.' After that meeting in Queen Street, I came to Canberra to meet with the Attorney-General Daryl Williams and, in rapid succession,

1 This speech was delivered in August 2008 at a function hosted by the Australian Public Service Commission. 
With the benefit of hindsight

to Sydney for an interview with Max Moore-Wilton. The upshot was that the Prime Minister announced my appointment on 8 December and I took up my position at Robert Garran offices a few weeks later on 24 January 2000.

\section{First day}

It's fair to say I was a bit on edge as I entered the front door on that first day. I was very conscious that I only knew about three of the several hundred people who worked there and none of the senior officers in the portfolio or the broader APS. I was also acutely aware that I had very little or no knowledge about many of the department's responsibilities, a limited background in public administration and no experience in dealing with a large number of portfolio agencies or negotiating the reefs and shoals of federal politics. However, I drew some comfort from the fact that I had gone through a similar experience twice before - at the Law Institute of Victoria and Legal Aid.

I adopted the same approach that got me through on those two occasions. That involved getting briefed and reading as much as I could as quickly as possible to learn how the department worked, consulting all relevant colleagues before making a decision and treating everyone with courtesy and respect. I made an effort to be friendly and open with all the staff, so I was surprised to receive some anonymous feedback towards the end of my first year that I had been perceived, at least in some quarters, to be a bit 'aloof'. I replied: 'Well, I am from Melbourne. We tend to be like that down there.'

I also found it interesting to observe how I was addressed on both formal and informal occasions. I made it clear I was perfectly happy to be called 'Rob' if people felt comfortable with that informality, but this was a bridge too far for some officers. To this day, some members of the Senior Executive Service who I have worked with for the whole eight and a half years have never called me anything but 'secretary', at least to my face. I might say this reservation didn't reach down to one young bloke who worked in the mail room. From day one, he called me 'mate'.

\section{Early impressions}

My early impressions of the department were that it was a good department faced with some difficulties. The major issue was that the Australian Government Solicitor had only just been established as a government business enterprise. Although that separation from the department had been coming for some years, its culmination in September 1999 brought home the stark reality that a 
large proportion of the department's principal function since 1 January 1901 providing legal advice to government - had been transferred to a new agency within the portfolio.

The department was facing the challenge of redefining its position in, and contribution to, government after this significant administrative change. The impact this challenge was having on the department was reflected in a recent staff survey and research project which produced some interesting insights. The consultants reported that the department was inwardly focused and that senior management placed a commendably high value on quality of services but a noticeably lower emphasis on client satisfaction. I also found comments by outsiders were instructive. One person said the department was 'struggling for relevance'.

An agency head commented that the government was 'looking for someone to ground the department'. Another secretary said: 'The department's not a player'. I referred to these comments in a speech I made to SES officers in February 2000. I said: 'These perceptions - right or wrong - are interesting. They indicate dissatisfaction with the department's current level of performance. But I understood them to be more disappointed than directly critical. Generally I took them to mean they felt that the department has a key role to play in Australian government but it was failing to meet all of the challenges of, and opportunities in, that role'.

In confronting these problems, I was able to draw on two useful aspects of my prior experience as a partner for fifteen years in a commercial law firm in the Melbourne CBD. First, as a solicitor, you are always working in a team of at least two - that is, yourself and your client. Often the team got quite a bit larger and could include, say, other solicitors, an accountant, a barrister, a town planner, an engineer and so on, depending on the issue at hand. Working as part of a team - even across professional silos - was second nature for me. Secondly, while solicitors usually make a very valuable contribution, they are not always the principal actor or decision maker. So working to assist other agencies to achieve their objectives was also a big part of my professional mindset. But more importantly, I can now see that the department's ability to leave old tasks behind and take on new ones as the demands of government change is actually one of its great strengths. That capacity has contributed to it remaining today as one of only three out of the first seven departments of state (along with Treasury and Defence) that have served the Commonwealth under their original name and broad charter since federation in 1901. 
With the benefit of hindsight

\section{APS - three early observations}

When I recall my first impressions of the broader Australian Public Service, three now outdated points stand out. In 2000, the Portfolio Secretaries Group was a real men's club. Helen Williams was the only female in the room in her role as Public Service Commissioner.

The collegiality Peter Shergold later promoted wasn't the strongest feature of Max Moore Wilton's management style. And policy, agency and even divisional silos had not yet been overcome by the positive, if time consuming, forces of connected or joined up government.

\section{Lessons learned before joining the APS}

As I am one of the few secretaries who have come directly to their position from outside the Australian Public Service, I have occasionally reflected on the experiences and lessons learned in other places that helped me make that transition. I know these observations will not be anything new to secretaries and agency heads but I am putting them on the record for officers coming through the ranks of the APS in case they find them helpful. Six things stand out. The first is the value of money.

\section{The value of money}

Fifteen years as a private practitioner permanently etched in my mind the principle that every dollar spent is a dollar less net profit. Like a lot of law firms, we used to approach the 1 April due date for tax payments with a great deal of trepidation. It was usually preceded by urgent instructions to fee earners to render accounts for all completed work and anxious negotiations with our bankers about an increase in the firm's overdraft. These are experiences you don't forget. As a result, I have regularly asked my colleagues putting forward a new policy or spending proposal: 'Would you spend this if it was your money?'

\section{Consultants}

My second lesson from previous experience involved the use of consultants. My colleagues will tell you I have a great scepticism about the value - or lack of value - provided by many consultants. This scepticism is reflected in a change I introduced into the department's CEIs which requires every consultancy engagement costing more than $\$ 20,000$ to be submitted to me for approval with a supporting business case. 
However, I acknowledge that there are two sorts of consultants - those that add value and those that don't. Consultants that add value bring particular skills and expertise to bear on and solve, or at least contribute to the solution of, a management problem. I like those consultants. Then there are consultants that talk in the current management gobbledegook, provide template recommendations and contribute little or nothing. I don't like those consultants.

But it is not always the consultants' fault. Sometimes, engaging a consultant is a management cop-out. It can seem to be an appealing solution to flick pass a difficult and ill-conceived project to a consultant. This can give the temporary impression that some progress is being made and the unsatisfactory result can be blamed on the consultant. When I was engaged in the restructure of legal aid in Victoria, I was asked on one occasion: 'Who is helping you?' I said: 'We are doing it ourselves,' and was greeted with a look of considerable surprise that managers could manage their organisation without the assistance of outside consultants. However, it is possible.

\section{Probity}

My third lesson was about probity. As one of my colleagues at Victoria Legal Aid observed: 'People only have a go at you if you're making a difference.' This observation was made after we had both received a freedom of information request seeking details of all of our credit card expenses from the then Victorian opposition which used the FOI Act for the sort of information the federal opposition gets at Estimates. The point is this. If people want to stick a spoke in your wheel, they will use whatever chance they have, even though it may be totally unrelated to the cause of their irritation. The most obvious happy hunting ground is travel and personal expenses. In Victoria, I recall that concerns about expenses and the attendant media publicity brought about the demise of the state governor, the head of the tourism authority and the CEO of Museum Victoria.

\section{Sound administrative process}

The next point I was well aware of before I came to the department is the protection offered by sound administrative process. One of my more difficult tasks as secretary of the Law Institute was to prosecute solicitors for misconduct before the Solicitors Board. Some solicitors took a dim view of my decisions and they challenged me in court. One strongly contested case is reported in the 1995 Victorian Law Reports. The three judges in the Court of Appeal analysed every step I had taken in deciding to bring that prosecution in a 37 page decision. Any flaw in the process I had followed would have lost the case. Fortunately, 
With the benefit of hindsight

the Court supported the referral to the Board and the High Court declined the solicitor's application for further leave to appeal. The case was finally heard by the Solicitors Board and the solicitor was found guilty of misconduct.

\section{Media}

The fifth useful experience was a background in dealing with the media. This started when I joined the Law Institute. We had an arrangement that the president, who held office for a year, represented the Institute in matters of legal policy and related areas. As executive director I would speak about administrative and educational issues and, as secretary, about disciplinary cases. This generally meant the president got the fun bits and I got left with questions like: 'What do you say to all the victims who have been defrauded by this $\$ 12$ million defalcation?' Secretaries aren't often put on the spot in the media but my media training was very useful preparation for Estimates. It taught me the value of careful and thorough preparation. It taught me the value of short, accurate statements that clearly answer the question. I also learnt the need to avoid negative and uncommon words because you can't convey a positive message in negative language and uncommon words cause the listener to lose the thread of what you are saying.

\section{Presentation}

The final lesson I brought with me is about presentation. In my media training, I was taught that viewers form opinions about people appearing on television roughly like this: 50 or 60 per cent on how they look, 30 per cent or more on how they sound and about 10 per cent on what they say. So I have always tried to look, sound and act like a secretary. Some people may think that is paying attention to appearance over substance but I disagree. Leadership is more about persuasion and example than direction. Establishing a view or perception of yourself as a leader your staff are prepared to accept is, in my opinion, a precondition to success. As it isn't possible for leaders in large organisations to get to know all the staff personally, leaders have to pay close attention to the way people form impressions about them from a distance. The point was really brought home to me on one early morning flight back to Canberra from an interstate meeting. I was in seat $1 \mathrm{C}$ and I observed my fellow traveller in $1 \mathrm{~A}$.

I was - naturally - wearing a business suit but he was in jeans, T-shirt, open plaid shirt with the sleeves partly rolled up, Birkenstock sandals and socks decorated with cartoon character Yosemite Sam and the word 'cute'. I thought to myself: 'This guy could be a software multi-millionaire for all I know but one thing's for sure - dressed like that, he will never be secretary of a department of state.' 


\section{The role of government lawyers}

Now I want to say something about how I see the role of government lawyers. I have always regarded good lawyers as legal problem-solvers - people who solve problems rather than create them. They take a close interest in a client's problem and accept personal responsibility to try to find an acceptable solution. I have to say I have not found this to be a universal view across the APS. One sometimes irritating aspect of my job is that, when attending a meeting, I have often been the only lawyer there.

On occasions, other participants (frequently led by Max) would look at me accusingly as if I was personally responsible for any perceived flaw in legislation, any court decision that went against the government or any legal advice, from whatever source, that the people present felt was unhelpful or impractical. To some extent, lawyers can provoke this attitude if we take too long to respond to clients or deliver turgid, verbose, impractical or unrealistic advice. To illustrate the point about the effectiveness of brevity and precision, I have sometimes relied on extracts from the Opinions of the Attorneys-General of the Commonwealth of Australia from 1901 to 1914 which was published by the department in 1981.

Those opinions provide great lessons in writing precise and useful advice. I will quote one of them to prove the point. The first Attorney-General, Alfred Deakin, was asked if the Commonwealth was liable to pay state stamp duty. On 20 January 1902, he dealt with the issue in these 55 words: 'I am of the opinion that stamp duty is not payable under State Acts, either by the Commonwealth or by individuals with whom the Commonwealth deals, in respect of any documents which are part of any transaction between the Commonwealth and any other party for the purpose of conducting the public business of the Commonwealth.' Of course, I have to allow that Alfred Deakin wasn't troubled by the need to take account of 105 years of High Court precedents. Nonetheless, we can certainly admire the simplicity and clarity of his advice.

\section{Language}

But while I have referred to legal examples, the objective of using simple and direct language is a challenge that can be put to everyone in the Australian Public Service. It may not be apparent to people who have lived in Canberra for all or a great part of their working life, but the nation's capital has a capacity for bureaucratic jargon that can be world class. I have identified two causes for this shortcoming. The main one seems to be the use of uncommon words that are not in everyday use and vague words that could have a number of meanings, leaving the listener to guess which one is intended. Words like 'drivers', 'methodologies', 
'vulnerabilities', 'capacity-building', 'interdependencies', 'multi-faceted strategies', 'in this space', 'convergence' and 'industry best practice' really make my eyes glaze over. My pet hates include long sentences, passive verbs, dense paragraphs, bureaucratic words that have lost their meaning and generic language that gives no hint of the actual subject matter under consideration.

Another major cause is the apparently mandatory use of acronyms that end up sounding like a secret code only capable of being understood by a privileged inner circle. One of the most insidious characteristics of this 'bureaucratese' is that it's infectious. It would be interesting to count how many times in a week we hear 'at the end of the day', 'going forward', 'in this space', 'we have to have a conversation around that issue' and so on. This communication style doesn't work well outside Canberra.

I was at a ministerial council meeting in Victoria a couple of years ago where we heard a report from Bob Abbott, the Mayor of the Sunshine Coast Regional Council, about the response to Cyclone Larry. Bob came across as a very capable but down-to-earth Aussie bloke who you'd like to have on your side in a fight. He delivered his report in a very direct, conversational, easy to understand way. Then a Commonwealth officer made a report from the federal perspective in Canberra jargon. At the morning tea break, I commented to one of the ministers how impressive Bob's presentation was. The minister replied: 'Yes - not like that other bloke. He was talking bull dust.'

These bad habits translate into written work as well. One of my significant failures that I am prepared to own up to in public is that I have not been able to cure some of my colleagues from including definitions where no definition is required or, even worse, including definitions that aren't used at all in the letter, document or submission. I point out on occasions that ministers will know that ASIO refers to the Australian Security Intelligence Organisation and AFP refers to the Australian Federal Police but I have to acknowledge that, in some areas of the department, that is a minority view.

\section{Policy pyramid}

One of the most perplexing aspects of this dilemma is that these forms of expression run completely counter to the process of evolving good policy, which demands that the policy be simply and clearly expressed. I think of this process as a policy pyramid. At the base of the pyramid, policy officers do the research, explore the issues, run the arguments, test the counter-arguments, consult externally and develop a reasoned proposal. As the proposal advances to branch heads, first assistant secretaries and so on, the proposal is refined and the issues narrowed. Eventually, when it gets to the minister or to cabinet, the 
essence of the proposal has to be distilled into a few words or, at most, a couple of sentences. While it may seem counter-intuitive, this means the proposal has to get shorter and simpler as it goes higher up the ladder so that it is in its simplest, most basic form when it is considered by Cabinet.

\section{Lessons learned in the APS}

Now I would like to mention a few important lessons I have learnt during my time in the Australian Public Service.

\section{Size and scope}

The first lesson was to adjust to the size and scope of the Australian government. It was like moving from the under 15s to the seniors overnight. APS colleagues were spread out in offices all over Canberra, across Australia and in major centres around the world. This physical separation was important because it meant that I didn't have the close and regular contact I was used to in smaller organisations. The Victorian government, which had previously been so important in my career, was now just one of eight governments the Commonwealth dealt with when it had to. It took a significant mental adjustment to see myself as part of the small group of senior officers at the top of the now about 150,000 strong APS juggernaut. Once I had overcome that initial shock, it seemed to me the basic principles of management applied in much the same way as before - they just involved more people and more dollars. Commonsense and sound judgment were still the most valuable management attributes.

\section{Information}

This leads to the second lesson which was how to find out what I needed to know to do my job. It came as a surprise to me to see how much useful and important information is obtained from informal and indirect means, including the media. On reflection, this also is a product of the size and breadth of the Australian government. Ministers are away from Canberra for most of the year, so you can't rely just on face-to-face meetings, phone calls, emails or SMS messages to keep up with their thinking or policy directions.

The former Prime Minister, John Howard, expressed this obligation well when he said in 1997 that the task of public servants is to 'recognise the directions in which a government is moving and be capable of playing a major role in developing policy options.' So I developed a few strategies to try to keep up to date with what was happening across government. They include reading 
all submissions to our ministers and replies to ministerial correspondence, regularly checking my Capital Monitors electronic information service, skim reading the summaries of the daily DFAT cables and reading many of the reports and bulletins from other departments and agencies that come across a secretary's desk. I also accepted lots of invitations to attend speeches, launches, functions, receptions and dinners because they were often a valuable source of both formal and off-the-record information. I served as President of the ACT Division of the Institute of Public Administration for two and a half years. One downside was that one colleague observed I would go to the opening of an envelope.

\section{Speed of decisions}

The third lesson was to get used to the speed with which decisions have to be taken at the top level of government to get through the volume of business. This was exemplified on one occasion when I was attending a joint budget meeting of the National Security and Expenditure Review Committees. There was a proposal to shift a function - and all the associated personnel and resources from one agency to another. I thought there were a couple of issues that merited discussion before a decision was taken. However, the PM said: 'This looks all right, doesn't it?' No minister objected and the matter was resolved in about 20 seconds. This example highlights two points. Firstly, the issue put to ministers for decision has to be simply stated (wherever possible) so they can just say yes or no. Secondly, the policy work that underpins the decision has to be fully developed so the steps needed to implement it are clearly laid out.

\section{Value of good process}

The next point is the value of good process. Obviously good process is essential to the Commonwealth's objectives in areas like merit-based selection and fair tendering. But it also has the benefit of protecting decision makers from any allegations of bias or unfair treatment. The important thing I learnt was that good process does not have to be slow or bureaucratic if the people in charge don't want it to be. So where the process is slow and clunky, senior officers should look at the way they are going about their business before they simply blame the applicable procedural rules.

\section{International perspective}

The final lesson I want to mention is learning to think nationally and internationally. One thing that really stands out when you come to the Commonwealth from a state service is the huge breadth of the national and international perspective confronted by the Australian Public Service. 
Secretaries spoke of ministers and senior officials from other countries as their counterparts in a way I had previously spoken about officials in similar positions in other states. But where it really hits home is when you travel the world on the country's business and meet people most Australians would only ever expect to see on television. I know this international aspect has always been a large part of many departments' activities. But it greatly increased for the Attorney-General's Department as its national security responsibilities became so important after September 11 .

So now I can look back on attending meetings with three US and two British Attorneys-General, two Home Secretaries, two Lord Chancellors, the Chief Justice of the United States, miscellaneous Law Lords, the President of Indonesia, the President of France (when he was the Minister for the Interior), the King of Cambodia, Senator John McCain, three heads of MI5, the head of the FBI, the head of the CIA, the Deputy US Secretary for Defence, two Secretaries for Homeland Security, the UN High Commissioner for Human Rights, one of the nine members of the Chinese Central Committee, high commissioners, ambassadors, senior officials from countries all over the world and so the list goes on.

Obviously a packed international itinerary is physically demanding, but two things have eased the burden. One is first class air travel and the other is the first class service provided by DFAT officers all over the world. What could be more welcoming in Beijing, Geneva, Washington, Jakarta, Ottawa, New York, Singapore or London than a smiling Aussie face at the top of the air bridge as soon as the plane door opens? This happy event is followed by facilitated clearance through immigration and customs, luggage being carried to a car waiting at the terminal entrance and assistance to go straight to your hotel room without passing reception. I once described travelling with a cabinet minister as being like travelling with minor royalty. But then I realised I had underestimated the service and I changed that to medium royalty. For many of you, that may all seem ho hum and old hat but I can tell you it was not an experience I ever expected when I was growing up in Moonee Ponds.

I think it's clear from what I have said so far that the Attorney-General's Department has grown and expanded over the last eight and a half years. This is illustrated by a few statistics.

On 30 June 2000, the department had 539 full time equivalent staff(excluding the Australian Protective Service and the Insolvency and Trustee Service Australia which operated as and were soon to become separate agencies). All of our staff were based in Canberra. In 2000- 01, the department had an appropriation of $\$ 99$ million and administered revenue of $\$ 225$ million. Today our total staff is around 1,550 officers. Our departmental appropriation for 2007-08 was \$218 
million and our total appropriation including administered funds was \$1.152 billion. We have offices in Canberra, Sydney, Mount Macedon, Perth, Jervis Bay and Christmas and Norfolk Islands as well as officers in Indigenous Coordination Centres around the country.

The Department has grown in two ways. First, a number of our longstanding divisions have got bigger. For example, the Protective Security Coordination Centre and the security law, criminal law and international law areas have all grown in response to greater government demands over the last few years. Because our role is frequently as part of a cross-portfolio team, a lot of this growth and the activity that has generated it often isn't readily apparent. So I was interested to hear Michael L'Estrange observe, when he addressed our SES officers not long after he came back from London, how much more often DFAT and the Attorney-General's Department were now working together on projects like free trade agreements or international engagements like RAMSI and the Enhanced Cooperation Program in PNG. I could add to that list, as further examples, our work with Defence on the legal aspects of our deployments to Iraq and Afghanistan, our participation with more than half the public service in the Northern Territory Emergency Response, the development of the Commonwealth Corporations Act with Treasury, our conduct of whole-ofgovernment counter-terrorism work including media awareness campaigns and our support for the National Counter Terrorism Committee.

The other way the department has grown is by acquiring new divisions or functions. They include the National Security Hotline, Emergency Management Australia, the AusCheck background checking service, film and literature classification, inter-country adoption, the Indigenous law and justice program, territories, establishing 65 family relationship centres and the development of a national personal property securities register. I have made the point to my colleagues more than once that getting a new task is an opportunity to do well but it doesn't come with a guarantee of success. The department is on trial each time that happens. Failure is a possibility. So each new task has to receive maximum care and attention. Despite that risk, the fact that we keep on getting more tasks suggests to me that we haven't done a bad job so far. In that sense, it has reinforced my view that the future of the department is bound up in its capacity to take on new tasks to keep its activities relevant to the needs of the government of the day. It also reminds me very much of private practice. Doing a job well often resulted in unsolicited referrals of more work. 


\section{A great privilege}

So you won't be surprised to know that I regard it as a huge privilege to have had the chance to participate in, and contribute to, the government of Australia at this national level and, in doing so, to work with outstanding colleagues in the department and across the public service. After Daryl Williams retired from parliament, I wrote him a letter in which I said: 'I doubt many permanent public servants fully understand what an honour it is - and how exciting it is - to come to Canberra as a departmental secretary after holding other career positions elsewhere'. Daryl replied: 'The only reservation I had in recommending your appointment was whether you would be able to cope with a system with which you were not familiar. With the benefit of hindsight, I can now see that there was not only no cause for concern but in fact your coming from outside the department was a positive advantage. You could see more clearly than someone inside how the operations could be improved.'

\section{Conclusion}

However, in all my time in Canberra, I knew I was only here while I held this position. So my time in the nation's capital has been like a fabulous working holiday. But eight and a half year's is enough. It's time for both me and the department to move on. I do so with the best of memories and with thanks to all of you for your support and encouragement during my tenure as secretary. 